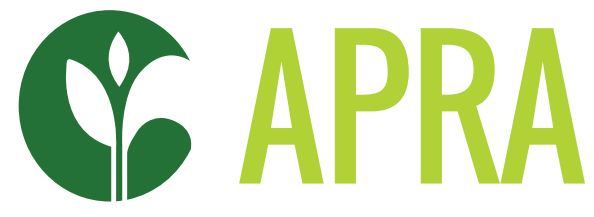

Agricultural Policy Research in Africa

\title{
USE OF CLIMATE-SMART AGRICULTURE PRACTICES AND SMALLHOLDER FARMER MARKET PARTICIPATION IN CENTRAL MALAWI
}

By Mirriam Matita, Ephraim Wadonda Chirwa, David Zingwe and Jacob Mazalale 


\section{CONTENTS}

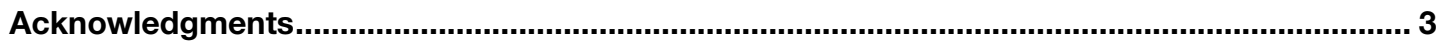

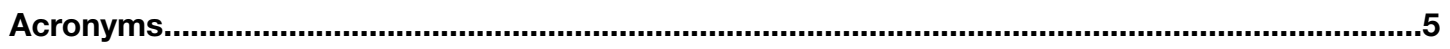

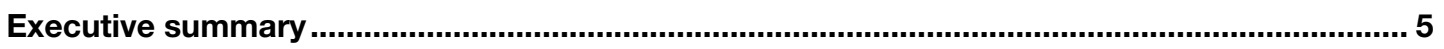

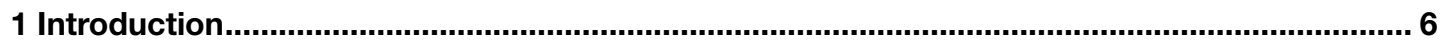

2 Drivers of agricultural technology adoption and links to market participation......................... 8

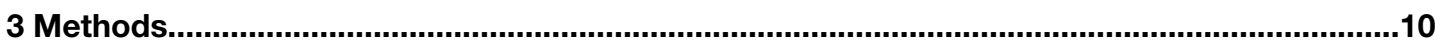

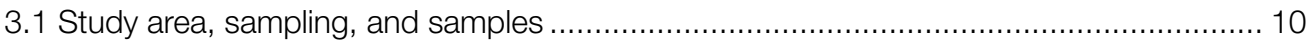

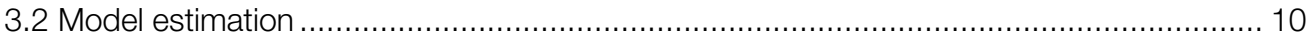

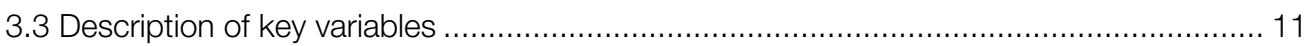

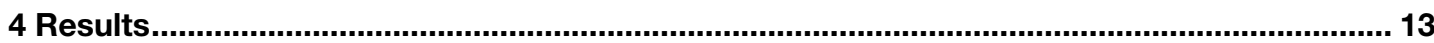

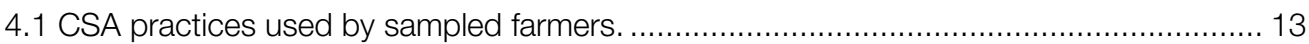

4.2 Descriptive statistics of variables used in estimated models....................................... 14

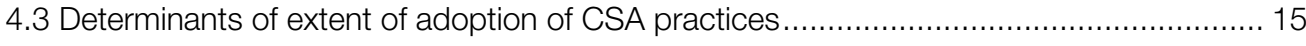

4.4 Effect of the extent of CSA practices adoption on market participation ........................... 16

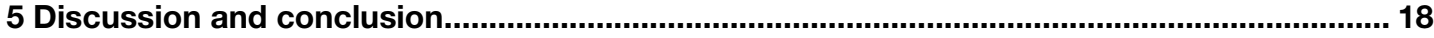

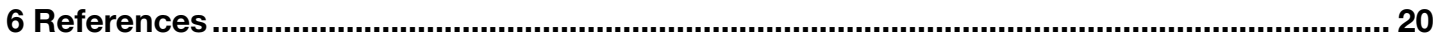

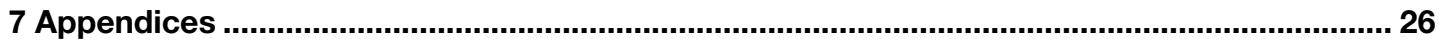

Tables

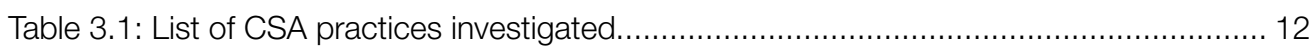

Table 4.1: Proportion of households using CSA practices (\%) ............................................. 13

Table 4.2: Quantiles of $\mathrm{HCl}$ and indicators of CSA practices used ..................................... 13

Table 4.3: Descriptive statistics of variables used in the models ......................................... 14

Table 4.4: Determinants of the extent of adoption of CSA practices.................................... 15

Table 4.5: Impact of adoption of CSA practices on the extent of market participation ........... 16

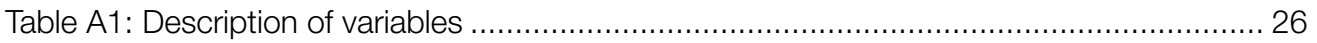

Table A2: Double-hurdle estimates of market participation .................................................. 27 


\section{ACKNOWLEDGEMENTS}

The authors are grateful to the farmers in the study locations, the research assistants, and Agricultural Policy Research in Africa (APRA) consortium members for making this research possible. We thank the reviewers for their helpful comments that significantly strengthened this paper including comments received at the PhD workshop held on 22-23 March 2021 organised by the Poverty Reduction Equity and Growth Network in collaboration with the German Institute for Global and Area Studies and Mercator Research Institute on Global Commons and Climate Change.

Mirriam Matita is an academic staff member at the Lilongwe University of Agriculture and Natural Resources but is currently pursuing her $\mathrm{PhD}$ studies with the Department of Economics at the University of Malawi. The late Ephraim Wadonda Chirwa was Emeritus Professor of Economics at the University of Malawi. David Zingwe (MA) is an associate researcher at Wadonda Consult Limited. Jacob Mazalale (PhD) is a lecturer in the Department of Economics at the University of Malawi.

This working paper is funded with UK aid from the UK government (Foreign, Commonwealth \& Development Office - FCDO, formerly DFID). The opinions are the authors and do not necessarily reflect the views or policies of IDS or the UK government. 


\section{ACRONYMS}

AGRA Alliance for a Green Revolution in Africa

APRA Agricultural Policy Research in Africa

CF control function

CSA climate-smart agriculture

FAO Food and Agriculture Organisation of the United Nations

FBM farm business management

GAP good agricultural practice

GoM Government of Malawi

HCl household commercialisation index

IV instrumental variable

NEPAD New Partnership for Africa's Development

SOAS School of Oriental and African Studies

TLU total livestock unit

UNDP United Nations Development Programme 


\section{EXECUTIVE SUMMARY}

In the past few decades, climate-smart agriculture (CSA) has been promoted to improve food security and raise incomes as a strategy for sustainable agricultural development. The adoption rates among smallholder farmers, particularly in Africa, remain low and have varied in different contexts. We investigated the market participation spill over effects from the adoption of CSA practices in central Malawi. We tested the hypothesis that the extent of the use of CSA practices in the past 10 years can lead to production surpluses that enable smallholder farmers to participate in markets and thereby increase agricultural incomes. Using survey data from 470 households in two districts of rural Malawi, we found a clear positive association between the number of CSA practices used and the extent of market participation. The findings suggest, among others, the need to intensify efforts to promote CSA adoption specifically over a longer period for benefits of the technologies to materialise. The adoption of CSA practices over time enhances crop market participation - an important aspect required for production sustainability as well as for transforming agriculture towards greater market orientation among smallholder farmers. 


\section{INTRODUCTION}

Agricultural productivity in sub-Saharan Africa has lagged compared to other developing regions (World Bank, 2009; NEPAD, 2013). The decimal agricultural performance has been associated with food insecurity, stagnant agricultural incomes, and poverty (FAO, 2020). The magnitude of these negative outcomes is more evident among the rural population in countries like Malawi where the majority depend on rain-fed agricultural livelihoods (AGRA, 2016). For instance, over half of Malawians are multidimensionally poor and gross national income per capita is at least three times lower than the sub-Saharan Africa average (UNDP, 2020). Furthermore, concerns about population growth vis-a-vis the increased demand for food and the urgency to provide the same sustainably have become apparent in national policy discourse (GoM, 2020). Recent trends in climate change-related stresses and shocks coupled with declining soil fertility amplify farming households' vulnerability, with some studies showing worsening climate-induced vulnerability to poverty (Shiferaw et al., 2014; Maganga, Chiwaula and Kambewa, 2021). This described situation has serious effects among smallholder farmers whose resilience to climate- and weather-related shocks and adaptation mechanisms are limited (Shiferaw et al., 2014; Makate et al., 2019; Murendo, Kairezi and Mazvimav, 2020).

In recognition of these challenges, multilateral organisations, development partners and national governments have been promoting the use of CSA practices as a strategy for sustainable agricultural development to increase food security and raise incomes. CSA is promoted in line with global food security objectives as an approach to sustainable farm production. According to FAO (2013), it is meant to address the intertwined challenges of food security, climate change adaptation and mitigation. Thus, there is recognition that agriculture itself impacts climate change (evident in emissions from the sector and practices that allow enhanced soil carbon sinks, for example) and that climate change threatens agricultural output (Hazell et al., 2010). CSA presents an integrative approach with an array of practices that supports the production of food in a more efficient way and builds greater resilience to climate change and shocks. The adopters of CSA practices conserve and enhance natural resources by being efficient in the way they use land, water, and other inputs in agricultural value chains. The three objectives of CSA include sustainably increasing agricultural production, building resilient agriculture and food systems that can adapt to climate change and reducing greenhouse gas emissions from agriculture (FAO, 2013). In practice, these objectives are implemented together at various levels, scales and time horizons addressing context-specific priorities to achieve increased incomes, food security and development. Several practices, including those for soil and water conservation, soil fertility management, crop portfolio management, fertiliser use, and agroforestry tree cultivation, are promoted in the CSA approach to farm production.

Wide literature exists on adoption rates and factors influencing the adoption of CSA practices (Mazvimavi and Towmlow, 2009; Teklewold, Kassie and Shiferaw, 2013; Andersson and D'Souza, 2014; Ngwira et al., 2014; Simtowe, Asfaw and Abate, 2016; Theriault, Smale and Haider, 2017; Hagos, Ndemo and Yosuf, 2018). Other studies examine the impacts of such adoption on outcomes such as productivity, food security and income, or poverty reduction (Corbeels et al., 2014; Arslan, Belotti and Lipper, 2016; Manda et al., 2016; Kotu et al., 2017; Hasan, 2018; Tambo and Mockshell, 2018). However, studies linking the extent of adoption of sustainable agricultural practices to market participation among smallholder farmers in Africa are scarce. One exception is a study by Awotide, Karimov and Diagne, (2016) on the impacts of improved rice adoption on market participation in Nigeria. Proponents of CSA assert that the adoption of sustainable agricultural practices can lead to improved soils, which in turn likely supports increases in crop productivity. With this increased crop production, households can obtain marketable surplus that can then be used to participate in output markets and therefore earn higher agricultural incomes more sustainably (Mccarthy and Brubaker, 2014; Richards et al., 2019).

There is, however, increasing concern that adoption rates of various CSA practices in Africa are low and varied (Teklewold, Kassie and Shiferaw, 2013; Arslan, Belotti and Lipper, 2016). In addition, the low adoption of sustainable agricultural practices inhibits increases in production surplus, essentially limiting 
the extent of crop market participation, resulting in lower incomes among smallholder farmers. This present study investigates the relationship between smallholder market participation and the extent of adoption of CSA practices in rural Malawi. Our unique contribution recognises that smallholder farmers adopt CSA practices through experimentation with multiple practices as observed by others (Wollni, Lee and Thies, 2010; Teklewold, Kassie and Shiferaw, 2013;) and that some of the practices cannot be used annually in certain circumstances. Therefore, we used a rich source of data that asked farmers about the use of CSA practices in the past 10 years. This is in line with the literature suggesting that longer periods of exposure are required to facilitate the adoption of some technologies (Holden et al., 2018; Musa et al., 2018). Our data provide wide information on the use of various CSA practices applicable in different agroecological and biophysical environments present in the study districts of Mchinji and Ntchisi in central Malawi where maize and groundnuts are the main food crops. Unlike previous studies, our multivariate analysis methods address any endogeneity issues arising from selection into technology adoption and market participation. 


\section{DRIVERS OF AGRICULTURAL TECHNOLOGY ADOPTION AND LINKS TO MARKET PARTICIPATION}

A large body of literature exists that identifies the drivers of agricultural technology adoption, drawing on household decision making models. A household decides to use and adopt CSA practices with the aim of maximising utility from leisure, own consumption of agricultural output, and consumption of market purchased goods subject to production, time, and income constraints (Barnum and Squire, 1979). CSA practices offers several benefits in different contexts that would motivate adoption, including enhancing the resilience of households to climate change-related shocks and promoting the efficient use of resources, which could, other things being constant, likely increase the profitability of agriculture. For instance, the literature suggests that crop diversification is among the adaptation strategies used by households in the face of increasing climate vulnerability in subSaharan Africa (Shiferaw et al., 2014; McCord et al., 2020). Other benefits from CSA adoption related to household food security. As demonstrated by Brüssow (2017) in Tanzanian households that adopted climate smart strategies were on average found to be more food secure than nonadopters. Relatedly, the adoption of conservation agricultural elements has been found to assist with soil moisture retention in Zambia and Zimbabwe (Thierfelder and Wall, 2009) with the potential to increase yields and reduce crop failure in periods of drought across Africa (Corbeels et al., 2014). A study by Kiptot, Franzel and Degrande (2014) demonstrates the substantial contribution of agroforestry to food security in Africa through increased crop and fruit production for food and income. Similarly, soil management technologies have been shown to improve smallholder farmer livelihoods in Kenya (Wanyama et al., 2010). Of course, these benefits are contextual depending on the agroecological and biophysical environment as well as other social and economic factors that drive the adoption of CSA.

Numerous studies have investigated drivers of the adoption of technologies that improve agricultural productivity. The decision by a farming household to use a technology and its extent of use is subject to several factors. The existing literature points to the relevance of information in creating awareness about a technology to kick-start the adoption process, making agricultural extension, and training a relevant factor influencing adoption (Giller et al., 2009; Arslan et al., 2014; Shiferaw et al., 2015; Arslan, Belotti and Lipper, 2016; Wossen et al., 2017; Hagos, Ndemo and Yosuf, 2018). Such information and interest in trying a technology may be strengthened by membership in farmer groups, as discovered in Nigeria regarding the use of improved rice varieties (Awotide, Karimov and Diagne, 2016), or in Honduras in relation to the adoption of soil conservation practices among farmers (Wollni, Lee and Thies, 2010). Furthermore, Corbeels et al. (2014) argue that good markets for purchased inputs and sale of produce are important for the adoption of conservation technologies in Africa. This is supported by the finding from Wollni, Lee and Thies (2010) that participation in organic markets in Honduras encouraged the use of soil conservation practices. Relatedly, for some practices, such as conservation agriculture, there is a trade-off between using crop residues as soil cover versus feeding them to animals, which has both costs and benefits for the farmer (Andersson and D'Souza, 2014; Corbeels et al., 2014).

There are also differences in the perceived shortand long-term benefits of CSA to be considered by a farmer when deciding to use a technology. For instance, Corbeels et al. (2014) demonstrates that increases in income with CSA adoption were less evident, possibly due to the long duration required for soil fertility improvement to yield results from land use change. This is more important in situations where the food security first strategy is key for the survival of smallholder farmers who are both producing and consuming economic agents (Singh, Squire and Strauss, 1986; Dillon and Barrett, 2017). Such perceptions about the period required to realise gains from CSA technologies may explain the lack of and/ or inadequate adoption of ex ante risk management strategies to cope with climate change. In relation to this, Coulibaly et al. (2015) found that farmers in Malawi largely adopted ex post strategies such as participating in seasonal labour markets and selling forest products rather than sustainable ones such as those promoted under CSA like farm irrigation, change of crop type/ variety and crop diversification. Additionally, constraints related to economic factors such as land, labour and capital availability prevent the implementation of some CSA practices (Nhemachena, Hassan and Chakwizira, 
2014; Pannell, Llewellyn and Corbeels, 2014; Awotide, Karimov and Diagne, 2016). These resources may be inadequate among smallholder households, therefore affecting the uptake of technologies.

The productivity improvements arising from adopting individual or a package of CSA practices are expected to support increased farm production. Such production increases could assure households of availability and access to food while allowing for increased marketable surpluses. Market participation is of course subject to market and price constraints, transaction, and infrastructure costs (Mather, Boughton and Jayne, 2013). However, a household would maximise its utility by deciding to participate in markets if expected utility from market participation is higher than expected utility from consumption. In relation to this, some studies have found, to varying degrees, that market participation reduces poverty and improves nutrition in households (Pingali and Rosegrant, 1995; Carletto, Corral and Guelfi, 2017; Ogutu and Qaim, 2019). One of the key drivers of market participation is output because without marketable surplus, households would not engage in markets. It therefore follows that the productivity-enhancing technologies that the CSA approach promotes would positively contribute to increased outputs. In addition, the resilience built will support livelihoods, making it easy for households to participate in markets knowing they could be cushioned by the resilient livelihood activities. Other drivers of the extent of market participation on the production side include gender, access to improved seeds, education, landholding, off-farm income and labour, to mention a few (Awotide, Karimov and Diagne, 2016). These factors indirectly affect the market orientation of households through the marketable surplus pathway. On the market side, factors that smoothen agricultural trade and reduce transactional costs also influence market participation (Pingali, Khwaja and Meijer, 2005). These factors include access to credit, social networks, and market information, as well as distance to the market. Using the data available, we controlled for some of these factors in our analysis. 


\subsection{Study area, sampling, and samples}

This study used cross-sectional data collected from the two districts Mchinji and Ntchisi in central Malawi. These central districts of Malawi are associated with high production of food and cash crops, including tobacco - the main export crop. Maize and groundnuts are key food crops grown by smallholder farmers in these districts with produced surpluses marketed. The agroecological and biophysiological characteristics of the locations make agricultural production more efficient in these locations (Asfaw et al., 2017). These areas are therefore considered to constitute 'the food basket' of the country. Thus, even though this study considers district fixed effects, the findings cannot be extrapolated to all regions in Malawi because the two study districts are in the same agroecological and livelihood zone. As a country, Malawi has 10 livelihood zones with different agricultural production potentials (GoM, 2005), and our study locations happen to be in the supposedly most production efficient zone (Asfaw et al., 2017). The study sites are therefore already advantageous in terms of production and CSA is more likely to be adopted by smallholder farmers.

The data used in this study were collected as part of a longitudinal study by APRA 1 investigating pathways to commercialisation and its outcomes (Matita et al., 2018). A sample of 470 households interviewed in September/October 2018 was used in the analysis. The households were drawn and tracked based on an original random sample interviewed in 2007 as part of the evaluation of the Agricultural Input Supply Programme in Malawi (SOAS et al., 2008; Matita et al., 2021). The follow-up dataset used in this study constitutes 42 per cent of the original households and 58 per cent of branching-out households composed of household members that were found to lead independent lives at the time of the survey. These households were engaged in farming activities in the 2017/18 agricultural season. Using a structured questionnaire, they provided information about their livelihoods, food security situation and experienced shocks, including adoption of agricultural technologies and CSA practices.

\subsection{Model estimation}

The following model was estimated to explain the effects of the extent of adoption of CSA practices on the extent of market participation among smallholder farmers:

$$
H C I_{i}=\beta_{0}+\beta_{1} C S A_{i}+\beta_{2} \boldsymbol{X}_{i}+\varepsilon_{i}
$$

where $\mathrm{HCI}_{i}$ is the household crop commercialisation index for household $i, C S A_{i}$ is the number of CSA practices used - an indicator of the extent of adoption by household $i, \boldsymbol{X}_{i}$ is a vector of control variables and $\varepsilon_{i}$ is the random error term.

Our estimation strategy recognises that the adoption of CSA practices can be endogenous and that the use of ordinary least squares in estimating $\beta_{1}$ may lead to biased estimates arising from the correlation between $C S A_{i}$ and $\varepsilon_{i}$. Farmers that adopt CSA practices may have unobserved characteristics that systematically differ from nonadopters. Consequently, these unobserved characteristics can correlate with the market-orientated behaviour of farmers. To address this endogeneity problem, we use the control function (CF) approach involving two stages (Woodridge, 2010).

In the first stage, we estimated determinants of the extent of adoption of CSA practices to obtain predicted residuals. The following model was estimated:

$$
C S A_{i}=\alpha_{0}+\alpha_{1} \boldsymbol{E} \boldsymbol{A}_{i}+\alpha_{2} \boldsymbol{H}_{i}+\alpha_{3} \boldsymbol{Z}_{i}+u_{i}
$$

where $C S A_{i}$ is the indicator of the extent of adoption of CSA practices by household $i, \boldsymbol{E A}_{i}$ is the vector of extension service access variables, $\boldsymbol{H}_{i}$ is a vector of household characteristics, $\boldsymbol{Z}_{i}$ is a vector of control variables including the number of agricultural shocks experienced by a household in the past two years and $u_{i}$ is the random error term. In estimating equation (2), the study did not account for plot-specific characteristics 
pertaining to soil and slope properties that may necessitate the adoption of some CSA practices as found relevant elsewhere (Arslan, Belotti and Lipper, 2016; Kotu et al., 2017) due to data limitations.

Given that the indicator of the extent of CSA adoption is a count variable, Poisson regression would be the likely model to be used. However, the Poisson assumes that adoption occurs with the same probability, an assumption that may not be valid in multiple adoption of CSA practices because experience and information gathered about prior technologies becomes useful in the decision (Wollni, Lee and Thies, 2010; Teklewold, Kassie and Shiferaw, 2013). Some studies model this relationship as a dichotomous choice of adopting a specific practice or package of practices using probit models (Arslan et al., 2014; Simtowe, Asfaw and Abate, 2016). Others use multinomial logit models to explain adoption behaviour across several practices. However, in a few studies, ordered probit has been used to capture the fact that farmers tend to adopt a package of practices partially or adopt multiple practices (Wollni, Lee and Thies, 2010; Teklewold, Kassie and Shiferaw, 2013). In this study, we used the ordered probit model.

The CF approach requires the inclusion of instrumental variables (IVs) in the first stage that correlate with adoption but are not correlated with the extent of market participation. Previous studies have used access to agricultural extension advice on technologies representing spillover effects of extension services, advice, and knowledge in a community (Arslan, Belotti and Lipper, 2016; Ragasa and Mazunda, 2018). Here, we use the average number of good agricultural practices (GAPs) for which households in a community received information. Intuitively, the adoption of CSA practices may be influenced by the number of technologies for which information is made available. Information and knowledge on different technologies is largely lacking among smallholder farmers in sub-Saharan Africa (Shiferaw et al., 2015). Improving access to extension information could facilitate experimentation and peer learning, especially among the early adopters that try technologies when the associated costs and risks are unknown in their setting. However, there is no reason to suspect that information on GAPs might influence how much of the harvested crop should be sold, especially in this context, where smallholder farmers largely produce for subsistence, with market participation decisions made after production. The costs associated with receipt of extension information may therefore be regarded as a fixed transaction cost (Key, Sadoulet and Janvry,
2000). In any case, a new set of factors may have to be considered for the decision on how much output to sell such as food requirements versus marketable surplus, availability of markets, and their risks - which at the marketing point have less to do with whether they received information on GAPs or not. This IV was found to significantly influence the adoption of CSAs but did not correlate with the outcome of interest using pairwise correlation. The variable was further included in both models to test for its exogeneity.

In the second stage, the predicted generalised residuals from the first stage are used as one of the covariates in estimating equation (1). A significant coefficient of the residuals in equation (1) implies endogeneity and inclusion of residuals correct for the bias in $\boldsymbol{\beta}_{1}$, while an insignificant coefficient implies that equation (1) can produce an unbiased estimate of $\boldsymbol{\beta}_{\mathbf{1}}$ when residuals from the first stage are excluded in the estimation. Here, the impact of CSA on the extent of market participation models is estimated using fractional logit models because the dependent variable crop commercialisation index is censored taking values between zero and one (Woodridge, 2010). Several variables influencing farmer market participation are controlled for, consistent with the existing literature (Pender and Alemu, 2007; Jaleta, Gebremedhin and Hoekstra, 2009; Wale and Baiyegunhi, 2015; Kabiti et al., 2016; Woldeyohanes, Heckelei, and Surry, 2017; Mmbando, Ogutu and Qaim, 2019; Rubhara and Mudhara, 2019), including receipt of subsidised farm inputs ${ }^{2}$ and an indicator of household food security the coping strategy index calculated based on Maxwell, Vaitla and Coates (2014). To check the consistency of the results, we employed the double-hurdle estimation, which allows for selectivity into market participation, as applied in other studies (Mather, Boughton and Jayne, 2013; Sibande, Bailey and Davidova, 2017).

\subsection{Description of key variables}

Our dependent variable, the household commercialisation index $(\mathrm{HCl})$, was calculated as the total value of agricultural output that was sold or planned to be sold from the 2017/18 agricultural season by the household, consistent with others (Carletto, Corral and Guelfi, 2017; Sibande, Bailey and Davidova, 2017). The $\mathrm{HCl}$ take the values between zero and one, with the latter indicating no market participation and the former indicating complete sale of what is produced. We used the selling prices stated by farmers to compute the value of all crops cultivated by the household. 
The main explanatory variable is the extent of adoption of CSA represented by the count of CSA practices used by the households in the past 10 years. Households were asked if in the past 10 years they have used any soil fertility improvement, soil and water conservation or cultivated agroforestry tree crops as listed in Table 3.1. The use of the CSA practices in the past can be intermittent over the reference period. Furthermore, our data did not include questions that could be used to verify continued use of the practices in the year of study. To capture usage, we created a dummy variable equal to one or zero, to indicate if a household had used a CSA practice. This approach to defining the variables, however, does not reflect the differences in the intensity of use. For example, some farmers may apply the recommended rate of manure, while others may apply far less than the recommended rate. However, in our approach, they are all treated as having used the technology. Using the different CSA dummy variables, we created a total count of practices used by the farmer that was used in the econometric modelling.

It is hypothesised that the greater the extent of use of CSA practices, the more improved soils become and the higher the productivity, leading to more marketable surplus, hence greater engagement of the household with the output market and a higher level of market participation - consistent with the aims of CSA to increase incomes. As previously mentioned, the modelling controls for different household socioeconomic and farming characteristics. However, we failed to account for the possibility that some unobserved characteristics might influence the extent of market participation and the adoption of CSA practices at the same time - for example, risks and time preferences. This is an area that future investigation might therefore consider. Table A1 provides the description of the variables and expected sign of relationship with extent of CSA practices adoption and market participation.

Table 3.1: List of CSA practices investigated

\begin{tabular}{|c|c|c|}
\hline Soil fertility improving & Soil and water conservation & Fertiliser trees \\
\hline 1. Crop residue & 9. Grass strips & \multirow{8}{*}{$\begin{array}{l}\text { 17. Any fertiliser tree (Tephrosia, } \\
\text { Gliricidia, Sesbania, Faidhebia) }\end{array}$} \\
\hline 2. Animal manure & 10. Contour ridges & \\
\hline 3. Inorganic fertiliser & 11. Bench terraces & \\
\hline 4. Legume cover crop & 12. Drainage channels & \\
\hline 5. Compost & 13. Pit planting & \\
\hline 6. Intercropping & 14. Box ridges & \\
\hline 7. Crop rotation & 15. Swales & \\
\hline 8. No tillage & 16. Infiltration pits & \\
\hline
\end{tabular}

Source: Authors' own 


\section{RESULTS}

\subsection{CSA practices used by sampled farmers}

Table 4.1 presents the proportion of households using various CSA practices. The top two practices reported by over 80 per cent of the households included crop rotation and application of inorganic fertiliser. This could be attributed to the government large-scale input subsidy programme that provides inorganic fertilisers and increased rotation of maize cultivation with legume crops. The proportion of farmers in our sample who received subsidised farm inputs was only 7 per cent but approximately 61 per cent of the farmers purchased commercial inorganic fertilisers in the 2017/18 farming season. It seems that over the past 10 years in question the technologies were taken

Table 4.1: Proportion of households using CSA practices (\%)

\begin{tabular}{|l|l|l|l|l|l|}
\hline Variable & Mean & Std. dev. & Variable & Mean & Std. dev. \\
\hline Crop residue & 0.59 & 0.49 & Grass strips & 0.33 & 0.47 \\
\hline Animal manure & 0.52 & 0.50 & Contour ridges & 0.27 & 0.44 \\
\hline Inorganic fertiliser & 0.89 & 0.31 & Bench terraces & 0.11 & 0.31 \\
\hline Legume cover & 0.33 & 0.47 & Drainage channel & 0.38 & 0.49 \\
\hline Compost & 0.37 & 0.48 & Pit planting & 0.06 & 0.23 \\
\hline Intercropping & 0.50 & 0.50 & Box ridges & 0.43 & 0.50 \\
\hline Crop rotation & 0.81 & 0.39 & Swales & 0.03 & 0.17 \\
\hline No tillage & 0.13 & 0.34 & Infiltration pits & 0.04 & 0.20 \\
\hline Any agroforestry tree & 0.33 & 0.47 & - & - & - \\
\hline Number of observations & & 470 & & \\
\hline
\end{tabular}

Notes: All variables are dichotomously equal to 1 for the stated practice and 0 otherwise for the base category.

Source: Authors' own

Table 4.2: Quantiles of $\mathrm{HCl}$ and indicators of CSA practices used

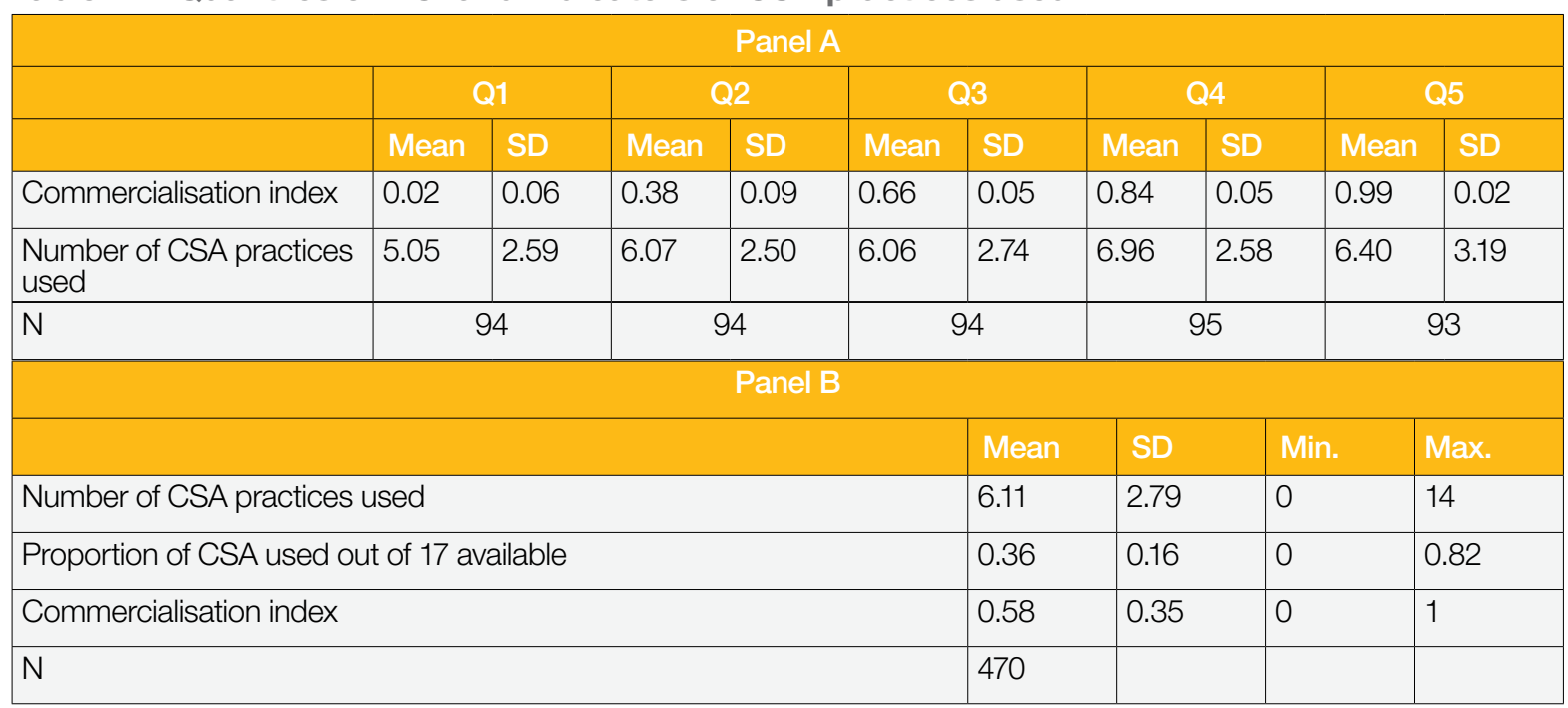

Notes: Panel A presents the mean and standard deviation (SD) by quantiles (Q1 to Q5) of the HCl. Panel B shows descriptive statistics for the different measures of CSA practices used in this paper.

Source: Authors' own 
up by farmers irrespective of programme participation, signifying technology diffusion. We found that no tillage was the least commonly used technology for improving soil fertility. The most used soil and water conservation practices in the past 10 years were box ridges, drainage channels and grass strips, which were reported by 43 , 38 and 33 per cent of the farmers, respectively, while swales, infiltration pits and pit planting were used by a few households. Agroforestry trees have been planted by 33 per cent of the sample in the past 10 years.

In Table 4.2, we present quantiles of the household crop commercialisation index and indicators of the extent of adoption of CSA practices. The least commercialised farmers in quantiles 1 and 2 sold 3 per cent and 38 per cent of their produce, respectively, while those in quantile 3 sold 66 per cent of their produce (panel A). The quantile differences in the extent of market participation were statistically significant at the 1 per cent level. On average, the extent of market participation defined by the $\mathrm{HCl}$ is estimated at 58 per cent of crop produce (panel B). On average, households used six of the CSA practices for which information was sought, representing 33 per cent of practices being used. The least commercialised households (in quantile 1) adopted only five CSA practices. Using Bonferroni's adjustment for pairwise correlation analysis, we observed significant differences between quantiles 1 and mean values obtained in quantiles 4 and 5 for the number of CSAs and proportion of those technologies used.

\subsection{Descriptive statistics of varialbles used in estimated models}

In Table 4.3, we present descriptive statistics of the variables used in estimated models. The average age of household heads was 41 years, and most of them were male-headed with a maximum of eight years of education in the household. Widespread receipt of extension messages was reported by 85 per cent of the households with the average number of GAPs for which extension advice was received at seven. Approximately 36 per cent reported the presence of lead farmers in their community. The households

Table 4.3: Descriptive statistics of variables used in the models

\begin{tabular}{|c|c|c|c|c|}
\hline Variable & Mean & Std. dev. & Min. & Max. \\
\hline Age of household head (years) & 41.0 & 16.21 & 17 & 90 \\
\hline Male-headed household (0/1) & 0.83 & 0.38 & 0 & 1 \\
\hline Maximum years of schooling in household & 8.16 & 3.36 & 0 & 22 \\
\hline Adult equivalents & 4.23 & 2.13 & 1 & 15 \\
\hline Asset index & 1.33 & 0.58 & 0 & 1.8 \\
\hline Total livestock units (TLU) & 0.52 & 1.43 & 0 & 18 \\
\hline Received any agriculture extension $(0 / 1)$ & 0.85 & 0.36 & 0 & 1 \\
\hline Received extension on farm business management $(0 / 1)$ & 0.40 & 0.49 & 0 & 1 \\
\hline Community has a lead farmer $(0 / 1)$ & 0.36 & 0.48 & 0 & 1 \\
\hline Land holding size (ha) & 1.60 & 2.89 & 0 & 40 \\
\hline Number of crops cultivated & 2.99 & 1.55 & 1 & 11 \\
\hline Plot managed by male head (0/1) & 0.70 & 0.46 & 0 & 1 \\
\hline Plot managed by female head (0/1) & 0.16 & 0.36 & 0 & 1 \\
\hline Male head makes crop income use decisions (0/1) & 0.67 & 0.47 & 0 & 1 \\
\hline Female head makes crop income use decisions (0/1) & 0.18 & 0.39 & 0 & 1 \\
\hline Household hired agricultural labour (0/1) & 0.31 & 0.46 & 0 & 1 \\
\hline Household has a member of farmer club (0/1) & 0.13 & 0.33 & 0 & 1 \\
\hline Household obtained credit (0/1) & 0.09 & 0.29 & 0 & 1 \\
\hline Household received subsidised fertiliser (0/1) & 0.07 & 0.26 & 0 & 1 \\
\hline Household purchased commercial fertiliser (0/1) & 0.60 & 0.49 & 0 & 1 \\
\hline Number of GAPs with extension provided & 7.23 & 6.02 & 0 & 19 \\
\hline Number of observations & \multicolumn{4}{|l|}{470} \\
\hline
\end{tabular}

Notes: $(0 / 1)$ indicates dichotomous variables for the stated category equal to 1 , otherwise equal to 0 for the base category.

Source: Authors' own 
cultivated, on average, 1.60ha of land, with most plots managed by male heads (70 per cent) relative to female heads (16 per cent). Similarly, male heads tended to make most of the decisions on crop sales income relative to female heads. Hiring of agricultural labour was observed among 31 per cent of the farmers, with 13 per cent having a household member participating in a farmer club and 9 per cent obtaining any credit. Only 7 per cent received subsidised farm inputs in the 2017/18 farming year with many - estimated at 61 per cent purchasing commercial fertiliser on the market. The proportion of households with a member in community farmer groups was estimated at 13 per cent.

\subsection{Determinants of extent of adoption of CSA practices}

Table 4.4 presents the regression results on determinants of the extent of adoption of CSA practices from an ordered probit estimation. Overall, the model was significant judging by the obtained probabilities for the Wald statistic. Our IV, the intensity of receipt of
GAP information, was statistically significant, implying that the number of CSA practices adopted is likely to be greater with increased intensity of receipt of GAP information. This finding is consistent with the strong and positive association between receipt of agricultural extension services, participation in farmer clubs and presence of a lead farmer in community and likely adoption of higher number of CSA practices. We further found a significant positive relationship between the adoption of CSA and maximum years of education in the household $(p<0.01)$. The number of crops cultivated was also associated with a significantly higher number of CSA practices being used. However, we failed to find a relationship between the number of CSA practices adopted and variables such as land, household size and hiring of agricultural labour, indicating that these variables do not present constraints to the extent of technology adoption. This corroborates findings elsewhere in Zambia (Arslan et al., 2014). This could be because here adoption is considered over a longer period - the past 10 years - and therefore current land and household size as well as hiring of agricultural

Table 4.4: Determinants of the extent of adoption of CSA practices

\begin{tabular}{|c|c|c|}
\hline Dependent variable: number of CSA practices used & Coeff. & Robust SE \\
\hline Age of household head & 0.001 & $(0.004)$ \\
\hline Male-headed household & 0.120 & $(0.146)$ \\
\hline Maximum years schooling in household & $0.055^{\star \star \star}$ & (0.015) \\
\hline Adult equivalent & -0.014 & $(0.030)$ \\
\hline Asset index & 0.026 & (0.097) \\
\hline TLU & 0.010 & $(0.028)$ \\
\hline Received any agriculture extension $(0 / 1)$ & $0.306^{\star \star}$ & $(0.145)$ \\
\hline Presence of lead farmer (0/1) & $0.209^{\star \star}$ & $(0.106)$ \\
\hline Land (ha) & 0.019 & $(0.014)$ \\
\hline Number of crops cultivated & $0.092^{\star \star \star}$ & (0.031) \\
\hline Plot managed by male head $(0 / 1)$ & -0.068 & $(0.108)$ \\
\hline Household hired agriculture labour (0/1) & 0.121 & (0.111) \\
\hline Household has member of farmer club (0/1) & $0.341^{\star \star}$ & (0.161) \\
\hline Average number of GAPS with extension received & $0.231^{*}$ & $(0.122)$ \\
\hline Number of agricultural shocks & -0.014 & (0.031) \\
\hline Coping strategy index & -0.008 & $(0.005)$ \\
\hline Original household (0/1) & 0.192 & (0.162) \\
\hline Pseudo R-squared & 0.038 & \\
\hline Wald Chi-squared & 96.406 & \\
\hline Log pseudolikelihood & $-1096.8982^{\star \star \star}$ & \\
\hline $\mathrm{N}$ & 470 & \\
\hline
\end{tabular}

Notes: Table presents regression results of the determinants of the extent of CSA practices adoption from the ordered probit model. Standard errors in parentheses. ${ }^{*} p<0.10,{ }^{* \star} p<0.05,{ }^{\star * \star} p<0.01$

Source: Authors' own 
labour may not influence the use of some technologies in the past. Additionally, Andersson and D'Souza (2014) explain that in the Malawi context, concerns about land degradation and associated recurrent food shortages have not triggered increased intensity of CSA adoption - contrary to expectations.

\subsection{Effect of the extent of CSA practices adoption on market participation}

Table 4.5 shows regression estimates of the effect of the extent of CSA practices adoption on the level of market participation. The inclusion of the CF residuals term from stage one models on determinants of CSA adoption was statistically insignificant. Therefore, endogeneity in technology adoption was not an issue for our sample. Our analysis further checked whether there was any selectivity into market participation among the study households that could influence the level of participation. This was conducted using a double-hurdle estimation. The obtained inverse Mills ratio was not significant, implying that there was no selectivity into market participation for the study sample (see results in Table A2). Therefore, we interpreted the results from our preferred model - the fraction logit estimation without residual term. This model was significant overall judging by the obtained Wald statistic $(p<0.01)$.

Table 4.5: Impact of adoption of CSA practices on the extent of market participation

\begin{tabular}{|c|c|c|c|}
\hline $\begin{array}{l}\text { Dependent variable: number of CSA practices } \\
\text { used }\end{array}$ & Coeff. & SE & $\begin{array}{l}\text { Average marginal } \\
\text { effects }\end{array}$ \\
\hline Number of CSA practices & $0.074^{\star \star \star}$ & $(0.026)$ & 0.016 \\
\hline Age of household head & 0.005 & $(0.007)$ & 0.001 \\
\hline Male-headed household & 0.003 & $(0.213)$ & 0.001 \\
\hline Maximum years schooling in household & $0.041^{*}$ & $(0.023)$ & 0.009 \\
\hline Adult equivalent & $-0.090^{\star *}$ & $(0.039)$ & -0.020 \\
\hline Asset index & 0.040 & $(0.140)$ & 0.009 \\
\hline TLU & 0.056 & $(0.055)$ & 0.012 \\
\hline Received FBM extension & 0.237 & $(0.145)$ & 0.052 \\
\hline Presence of lead farmer (0/1) & 0.203 & $(0.149)$ & 0.045 \\
\hline Land (ha) & 0.013 & $(0.036)$ & 0.003 \\
\hline Received off-farm income (0/1) & 0.150 & $(0.155)$ & 0.033 \\
\hline Number of crops cultivated & $0.225^{\star \star \star}$ & (0.052) & 0.050 \\
\hline Male head makes decisions on income (0/1) & 0.131 & $(0.158)$ & 0.029 \\
\hline Hired agricultural labour (0/1) & -0.042 & $(0.176)$ & -0.009 \\
\hline Obtained credit $(0 / 1)$ & 0.058 & $(0.255)$ & 0.013 \\
\hline Farm input subsidy beneficiary $(0 / 1)$ & $0.467^{\star}$ & $(0.271)$ & 0.103 \\
\hline Bought commercial fertiliser (0/1) & 0.077 & $(0.153)$ & 0.017 \\
\hline Member of farmer club (0/1) & 0.153 & $(0.226)$ & 0.034 \\
\hline Coping strategy index & -0.007 & $(0.007)$ & -0.002 \\
\hline Mchinji District (0/1) & $0.288^{\star \star}$ & $(0.137)$ & 0.063 \\
\hline Original household (0/1) & $-0.646^{\star \star \star}$ & $(0.237)$ & -0.144 \\
\hline Constant & $-1.243^{\star \star \star}$ & $(0.423)$ & - \\
\hline Pseudo R-squared & 0.074 & & \\
\hline Wald Chi-squared & 104.948 & & \\
\hline Log pseudolikelihood & $-296.2205^{\star \star \star}$ & & \\
\hline $\mathrm{N}$ & 470 & & \\
\hline
\end{tabular}

Notes: Table presents regression results of the determinants of the extent of CSA practices adoption from the ordered probit model. Standard errors in parentheses. ${ }^{*} p<0.10,{ }^{* *} p<0.05,{ }^{\star \star *} p<0.01$

Source: Authors' own 
We found the expected positive relationship between CSA adoption and the household crop commercialisation index. This association was statistically significant at 1 per cent. When an additional CSA practice was used, a household experienced a 1.6 per cent increase in the predicted extent of market participation. With respect to household characteristics, we found a weak but positive relationship between maximum years of schooling in a household and market participation $(p<0.10)$, with about 1 per cent increase in the extent of crop marketing. However, there was a significantly negative relationship between the extent of market participation and adult equivalents. This contradicts the assertion that household size provides family labour that may increase crop production with likely surplus output that can be used for marketing (Rios. Masters and Shively, 2008; Martey, Al-hassan and Kuwornu, 2012; Radchenko and Corral, 2018). It is possible that large household sizes increased the food requirements for households in this context where food insecurity and poverty were persistent. In addition, other studies have shown that own-produced food meant for consumption is sold by households in a typical distress selling fashion (Jones, 2016; Carletto, Corral and Guelfi, 2017), which may explain the negative relationship. In addition, the need to attain food security limited the extent of crop sales - a finding also reported by Chirwa and Matita (2012). As expected, the results indicate that original households used significantly smaller number of CSA practices than branching out households. This could be due to aging and the associated reduction in physical labour to engage in agricultural activities.

Further findings showed a positive association between the number of crops cultivated and the extent of crop marketing, indicating that crop diversification supported market participation for households. With diverse crop production, households could easily allocate crops for food and sale purposes, as found in another study with respect to maize marketing (Sibande, Bailey and Davidova, 2017). We also found that residence in Mchinji District significantly influenced the extent of crop marketing relative to Ntchisi District, suggesting that location-specific factors are important for market participation. Although both districts are in the same agroecological zone, Mchinji District is relatively more developed in terms of infrastructure and economic activity than Ntchisi District. Furthermore, Mchinji borders the Zambia district of Chipata, which facilities agricultural trade (Chirwa and Matita, 2015).

With respect to market factors, we found that contrary to our expectation, credit access, participation government farm inputs subsidy programme, purchase of commercial fertilisers, hiring of labour and membership in farmer clubs were not associated with a greater extent of market participation. Apparently, credit financing for agriculture is largely non-existent, with most farmers using their own savings for input purchases in Malawi and across other sub-Saharan countries (Adjognon, Liverpool-tasie and Reardon, 2017). In our sample, only 9 per cent reported obtaining credit, but we could not ascertain if it was used for agricultural purposes due to data limitations. For households receiving subsidised farm inputs and purchasing commercial fertilisers, it is likely that they largely do so for purposes of producing their own food for consumption, a typical occurrence among subsistence farmers, while in other settings, these same technologies could increase marketed surplus (Mather, Boughton and Jayne, 2013; Carletto, Corral and Guelfi, 2017; Sibande, Bailey and Davidova, 2017). Additionally, farmer organisations present in rural settings seem to be biased towards production and not marketing, and where they invest in market value chains, farmers fail to sustain project activities beyond the lifespan of assisting projects (Chinsinga and Matita, 2021). In any case, farmer organisations in the study districts were found to be lacking in funds, performance of functions, and the associated structures to effectively engage in markets without external support (Chimombo et al., forthcoming). 


\section{DISCUSSION AND GONCLUSION}

This present study set out to assess the relationship between the extent of adoption of CSA practices and market participation among smallholder farmers. This work contributes to existing knowledge by determining drivers of the extent of adoption of CSA practices using a rich dataset with 17 CSA practices used by smallholder farmers in the past 10 years in various categories, namely, agroforestry tree crops cultivation, water and soil conservation, and soil fertility management. The indicator of CSA adoption employed reflects our recognition that farmers may not necessarily use these practices annually, and adoption often occurs through an experimentation process of what works or not. It was defined as a count of CSA practices used to capture the extent of adoption rather than the usual dummy variable approach which only indicates the decision of whether to adopt a particular technology. We contribute to knowledge on intermediate outcomes of such adoption with particular focus on the spill over effects on market participation, a step towards increased agricultural commercialisation.

We found that, on average, households adopted six CSA practices with a maximum of 14 practices out of the 17 for which information was sought (proportion of 36 per cent). Crop rotation and application of inorganic fertilisers were the top practices used in line with trends in other sub-Saharan African countries, largely due to opportunities for both food and marketing of grain legumes (Giller et al., 2009) as well as government input subsidies on legume seeds and fertilisers over the period in Malawi (Nkhoma, 2018). The least commonly used soil fertility management practice was no tillage. Approximately 33 per cent of the sample households cultivated agroforestry tree crops in the past 10 years. Intercropping was also widespread for half of the sample, and approximately one-third used box ridges, drainage, and grass stripes to conserve soil and water.

The results indicated no evidence of an association between the extent of adoption of CSA practices and most socioeconomic factors (such as gender and age of household head, asset index and land), consistent with other studies (Arslan et al., 2014), although at odds with literature suggesting these present constraints on adoption (Andersson and D'Souza, 2014; Kotu et al., 2017; Musa et al., 2018; Tambo and Mockshell, 2018).
The only socioeconomic characteristic that we found significant in this assessment was maximum years of schooling in the household, signifying the importance of education in assimilating information about CSA practices and their use. This finding, while consistent with Wollni, Lee and Thies, (2010), departs from the tendency to investigate the role of education of the household head or farm managers only (Wossen et al., 2017; Musa et al., 2018; Tambo and Mockshell, 2018), which misses the combined effect of educating different members of a household on the adoption of farm technologies. The results obtained also confirm findings of other studies about the importance of extension in improving the adoption of CSAs (Knowler and Bradshaw, 2007; Teklewold, Kassie and Shiferaw, 2013; Arslan et al., 2014; Shiferaw et al., 2015; Awotide, Karimov and Diagne, 2016; Simtowe, Asfaw and Abate, 2016; Wossen et al., 2017; Musa et al., 2018). Membership in farmer clubs, presence of lead farmer and receipt of any extension services, including GAPs, emerged as strong predictors of adoption of CSA practices. These have been demonstrated to offer opportunities for networking and peer learning that assist in overcoming constraints to adoption, corroborating Corbeels et al.'s (2013) conclusion that dissemination strategy matters for improved adoption of technologies. The farmer-to-farmer extension branded lead farmer approach in Malawi has been found to be effective in promoting various technologies, including recommending the adoption of conservation agriculture to follower farmers based on their own familiarity and experience (Holden et al., 2018), although generally only a few farmers are reached by lead farmers (Ragasa and Niu, 2017).

Surprisingly, smallholder farmers' risk attitude, signified by the number of crops cultivated, was positively associated with the adoption of CSA practices, contrary to findings elsewhere in the Philippines (Mariano, Vallano and Fleming, 2012), where crop diversification did not matter for the adoption of certified seed technologies. We suspect that as farmers attempt to manage and adapt each crop to climate variation to avoid crop failure, different CSA practices are taken up in mitigation. Similar observations have been made by others (Shiferaw et al., 2014; Kuntashula et al., 2015; Brüssow, 2017; McCord et al., 2020). 
With respect to the extent of market participation, households sold on average 58 per cent of what was harvested, and a greater extent of crop marketing was associated with a higher number of CSA practices adoption. This finding suggests that CSA practices may be widely taken up by smallholder farmers that are market-oriented - a finding supporting Corbeels et al. (2013) that market opportunities must be considered when promoting technologies. Previous studies have also emphasised the importance of the adoption of technologies for market participation and resulting income increases. For example, the adoption of a combination of conservation agriculture practices was strongly associated with increases in incomes in several African countries (Tambo and Mockshell, 2018) as well as higher crop revenues (Ng'ombe, Kalinda and Tembo, 2017) and poverty reduction (Abdulai, 2016). Additionally, the adoption of several CSA practices has been found to increase yields with consequent increases in marketed surplus affecting household welfare (Arslan, Belotti and Lipper, 2016; Awotide, Karimov and Diagne, 2016; Brüssow, 2017). Together, these results provide important insights into the potential of using a combination of CSA practices over time to spur greater crop marketing.

In conclusion, this study found that the number of CSA practices adopted over a period likely increased crop marketing in central districts in rural Malawi among populations vulnerable to the effects of climate variability, low crop productivity and poor soil fertility. Interventions to promote CSA adoption using a variety of extension approaches supported the experimentation and takeup of CSA practices that worked in smallholders' environments over time. More importantly, increased adoption of CSA practices with associated yield increases greatly expanded marketable surplus among smallholder farmers, creating incentives for continued use of the technologies. The results demonstrate that with the adoption of CSA practices in the past 10 years, farmers likely benefitted in terms of increased income from crop sales, therefore supporting welfare. It seems that intensifying efforts to promote CSA adoption specifically over the long term allows gains from CSA practices to materialise. In sum, the adoption of CSA practices enhanced crop market participation spill over effects among smallholder farmers - an important aspect required for production sustainability as well as for transforming agriculture towards greater market orientation among smallholder farmers in Malawi and elsewhere in sub-Saharan Africa. 
Abdulai, A.N. (2016) 'Impact of conservation agriculture technology on household welfare in Zambia. Agricultural Economics', Agricultural Economics 47(6): 729-741. https://doi.org/10.1111/agec.12269.

Adjognon, S.G., Liverpool-tasie, L.S.O. and Reardon, T.A. (2017) 'Agricultural input credit in Sub-Saharan Africa : Telling myth from facts', Food Policy 67: 93-105. https://doi.org/10.1016/j.foodpol.2016.09.014.

AGRA. (2016) Africa Agriculture Status Report 2016: Progress towards Agricultural Transformation in Africa. Nairobi: AGRA.

Andersson, J.A. and D'Souza, S. (2014) 'From adoption claims to understanding farmers and contexts: A literature review of Conservation Agriculture (CA) adoption among smallholder farmers in southern Africa', Agriculture, Ecosystems and Environment 187: 116-132. https://doi.org/10.1016/j.agee.2013.08.008.

Arslan, A., Belotti, F. and Lipper, L. (2016) Smallholder productivity under climatic variability : Adoption and impact of widely promoted agricultural practices in Tanzania. ESA Working Paper No. 16-0). Rome: Food and Agriculture Organization of the United Nations.

Arslan, A., Mccarthy, N., Lipper, L., Asfaw, S. and Cattaneo, A. (2014) 'Adoption and intensity of adoption of conservation farming practices in Zambia', Agriculture , Ecosystems and Environment 187: 72-86. https://doi. org/10.1016/j.agee.2013.08.017.

Asfaw, S., Cattaneo, A., Pallante, G. and Palma, A. (2017) Impacts of modifying Malawi's farm input subsidy programme targeting. FAO Agriculutral Development Economics Working Paper No. 05. Rome: Food and Agriculture Organization of the United Nations.

Awotide, B.A., Karimov, A.A. and Diagne, A. (2016) 'Agricultural technology adoption, commercialization and smallholder rice farmers' welfare in rural Nigeria', Agricultural and Food Economics 4: 3. https://doi.org/10.1186/ s40100-016-0047-8.

Barnum, H.N. and Squire, L. (1979) 'An econometric application of the theory of the farm- household', Journal of Development Economics 6: 79-102.

Brüssow, K. (2017) 'Implications of climate-smart strategy adoption by farm households for food security in Tanzania', Food Security, 9:1203-1218. https://doi.org/10.1007/s12571-017-0694-y.

Carletto, C., Corral, P. and Guelfi, A. (2017) 'Agricultural commercialization and nutrition revisited: Empirical evidence from three African countries', Food Policy 67: 106-118. https://doi.org/10.1016/j.foodpol.2016.09.020.

Chimombo, M., Chinsinga, B., Mgalamadzi, L., Matita, M., Kaiyatsa, S., and Mazalale, J. (forthcoming) Interrogating the Effectiveness of Farmer Producer Organizations in Enhancing Smallholder Commercialization - Frontline Experiences from Central Malawi. APRA Working Paper. Brighton: Future Agricultures Consortium.

Chinsinga, B. and Matita, M. (2021) The political economy of the groundnut value chain in Malawi: Its re-emergence amidist policy chaos, strategic neglect and opportunism. APRA Working Paper 56. Brighton: Future Agricultures Consorium. Available at: https://opendocs.ids.ac.uk/opendocs/handle/20.500.12413/16679 (Accessed: 4 September 2021).

Chirwa, E.W. and Dorward, A. (2013) Agriculture Input Subsides; the recent Malawi experience (First Edit). Oxford: Oxford University Press. 
Chirwa, E.W. and Matita, M. (2012) From Subsistence to Smallholder Commercial Farming in Malawi : A Case of NASFAM Commercialisation Initiatives. FAC Working Paper 37. Brighton: Future Agricultures Consortium. Available at: https://opendocs.ids.ac.uk/opendocs/handle/123456789/2268 (Accessed: 7 March 2019).

Chirwa, E.W. and Matita, M. (2015) Space, Market and Employment in Agriculture Development, Malawi Country Report, Institute for Poverty, Land and Agrarian Studies Research Report No. 45. Cape Town: Institute for Poverty, Land and Agrarian Studies Research.

Corbeels, M., Graaff, J. De, Hycenth, T., Penot, E., Baudron, F., Naudin, K., Andrieua, N., Chirata, G., Schulerc, J., Nyagumboe, I., Rusinamhodzib, L., Traoref, K., Mzobag, H.D. and Aldowa, I.V., (2014) 'Understanding the impact and adoption of conservation agriculture in Africa: A multi-scale analysis', Agriculture, Ecosystems and Environment 187: 155-170. https://doi.org/10.1016/j.agee.2013.10.011.

Coulibaly, J.Y., Gbetibouo, G.A., Kundhlande, G., Sileshi, G.W. and Beedy, T.L. (2015) 'Responding to Crop Failure: Understanding Farmers' Coping Strategies in Southern Malawi', Sustainability 7: 1620-1636. https://doi. org/10.3390/su7021620.

Dillon, B. and Barrett, C.B. (2017) 'Agricultural factor markets in Sub-Saharan Africa: An updated view with formal tests for market failure', Food Policy 67: 64-77. https://doi.org/10.1016/j.foodpol.2016.09.015.

Dorward, A. (2009) 'Integrating Contested Aspirations, Processes and Policy: Development as Hanging In, Stepping Up and Stepping Out', Development Policy Review 27(2): 131-146.

FAO. (2013) Climate-Smart Agriculture Sourcebook. Rome: Food and Agriculture Organization of the United Nations.

FAO. (2020) Emergency Agriculture Food Survellience System (EMA-FSS): Evidence based decision support in emergency situation through provisionof data and information, COVID-19 Rapid Response. Rome: Food and Agriculture Organization of the United Nations.

Giller, K.E., Witter, E., Corbeels, M. and Tittonell, P. (2009) 'Conservation agriculture and smallholder farming in Africa: The heretics' view', Field Crops Research 114: 23-34. https://doi.org/10.1016/j.fcr.2009.06.017.

GoM. (2005) Malawi Baseline Livelihood Profiles Version 1. Lilongwe: Government of Malawi.

GoM. (2020) Malawi's Vision: An Inclusively Wealthy and Self-reliant Nation. Malawi 2063. Lilongwe: Government of Malawi.

Hagos, H., Ndemo, E. and Yosuf, J. (2018) 'Factors affecting adoption of upland rice in Tselemti district , northern Ethiopia', Agriculture and Food Security 7(58): 1-9. https://doi.org/10.1186/s40066-018-0210-4.

Hasan, K. (2018) 'Impact of climate-smart agriculture adoption on the food security of coastal farmers in Bangladesh', Food Security, 10: 1073-10888. https://doi.org/10.1007/s12571-018-0824-1

Hazell, P., Poulton, C., Wiggins, S. and Dorward, A. (2010) 'The Future of Small Farms : Trajectories and Policy Priorities', World Development 38(10): 1349-1361. https://doi.org/10.1016/j.worlddev.2009.06.012.

Heltberg, R. and Tarp, F. (2002) 'Agricultural supply response and poverty in Mozambique', Food Policy 27: 103-124.

Holden, S.T., Fisher, M., Katengeza, S.P. and Thierfelder, C. (2018) 'Land Use Policy Can lead farmers reveal the adoption potential of conservation agriculture? The case of Malawi', Land Use Policy 76(December 2017): 113123. https://doi.org/10.1016/j.landusepol.2018.04.048.

Jaleta, M., Gebremedhin, B. and Hoekstra, D. (2009) Smallholder commercialization: Processes, determinants and impact. Discussion Paper No. 18. Addis Ababa: International Livestock Research Institute.

Jones, A.D. (2016) 'On-Farm Crop Species Richness Is Associated with Household Diet Diversity and Quality in Subsistence- and Market-Oriented Farming Households in Malawi', The Journal of Nutrition 147(1): 86-96. https:// doi.org/10.3945/jn.116.235879.

Kabiti, H.M., Raidimi, N.E., Pfumayaramba, T.K. and Chauke1, P.K. (2016) 'Determinants of Agricultural Commercialization among Smallholder Farmers in Munyati Resettlement Area, Chikomba District, Zimbabwe', Journal of Human Ecology 53(1): 10-19. https://doi.org/10.1080/09709274.2016.11906951. 
Key, N., Sadoulet, E. and Janvry, A. De. (2000) 'Transactions Costs and Agricultural Household Supply Response', American Journal of Agricultural Economics 82(May): 245-259.

Khonje, M.G., Manda, J., Mkandawire, P., Hirpa, A. and Alene, A.D. (2018) Adoption and welfare impacts of multiple agricultural technologies: evidence from eastern Zambia', Agricultural Economics 49: 599-609. https:// doi.org/10.1111/agec.12445.

Kiptot, E., Franzel, S. and Degrande, A. (2014) 'Gender , agroforestry and food security in Africa', Current Opinion in Environmental Sustainability 6: 104-109. https://doi.org/10.1016/j.cosust.2013.10.019.

Knowler, D. and Bradshaw, B. (2007) 'Farmers' adoption of conservation agriculture: A review and synthesis of recent research', Food Policy 32(1): 25-48. https://doi.org/10.1016/j.foodpol.2006.01.003.

Kotu, B.H., Alene, A., Manyong, V., Hoeschle-, I. and Larbi, A. (2017) 'Adoption and impacts of sustainable intensification practices in Ghana', International Journal of Agricultural Sustainability 15(5): 539-554. https://doi. org/10.1080/14735903.2017.1369619.

Kuntashula, E., Kuntashula, E., Chabala, L.M., Chibwe, T.K. and Kaluba, P. (2015) 'The Effects of Household Wealth on Adoption of Agricultural Related Climate Change Adaptation Strategies in Zambia The Effects of Household Wealth on Adoption of Agricultural Related Climate Change Adaptation Strategies in Zambia', Sustainable Agriculture Research 4(4): 88-101. https://doi.org/10.5539/sar.v4n4p88.

Maganga, A.M., Chiwaula, L. and Kambewa, P. (2021) 'Climate induced vulnerability to poverty among smallholder farmers: Evidence from Malawi', World Development Perspectives 21(November 2020): 100273. https://doi. org/10.1016/j.wdp.2020.100273.

Makate, C., Makate, M., Mango, N. and Siziba, S. (2019) 'Increasing resilience of smallholder farmers to climate change through multiple adoption of proven climate-smart agriculture innovations. Lessons from Southern Africa', Journal of Environmental Management 231(October 2018): 858-868. https://doi.org/10.1016/j. jenvman.2018.10.069.

Manda, J., Alene, A.D., Gardebroek, C., Kassie, M. and Tembo, G. (2016) 'Adoption and Impacts of Sustainable Agricultural Practices on Maize Yields and Incomes: Evidence from Rural Zambia', Journal of Agricultural Economics 67(1): 130-153. https://doi.org/10.1111/1477-9552.12127.

Mariano, M.J., Vallano, R. and Fleming, E. (2012) 'Factors influencing farmers ' adoption of modern rice technologies and good management practices in the Philippines', Agricultural Systems 110: 41-53. https://doi. org/10.1016/j.agsy.2012.03.010.

Martey, E., Al-hassan, R.M. and Kuwornu, J.K.M. (2012) 'Commercialization of smallholder agriculture in Ghana: A Tobit regression analysis', African Journal of Agricultural Research 7(14): 2131-2141. https://doi.org/10.5897/ AJAR11.1743.

Mather, D., Boughton, D. and Jayne, T.S. (2013) 'Explaining smallholder maize marketing in southern and eastern Africa: The roles of market access, technology and household resource endowments', Food Policy 43: 248-266. https://doi.org/10.1016/j.foodpol.2013.09.008.

Matita, M., Chinsinga, B., Mgalamadzi, L., Mazalale, J., Chimombo, M., Stevier, K. and Chirwa, E.W. (2018) A Longitudinal Tracker Study of Groundnuts Commercilisation and Livelihood Trajectories in Malawi. APRA Research Note 1. Brighton: Futures Agricultures Consortium. Available at: https://opendocs.ids.ac.uk/opendocs/ handle/20.500.12413/14006 (Accessed: 21 May 2018).

Matita, M., Chirwa, E.W., Kaiyatsa, S., Mazalale, J. and Chimombo, M. (2021) Determinants of Smallholder Farmers' Livelihood Trajectories: Evidence from Rural Malawi. APRA Working Paper 50. Brighton: Futures Agricultures Consortium. Available at: https://opendocs.ids.ac.uk/opendocs/handle/20.500.12413/16479 (Accessed: 26 March 2021).

Maxwell, D., Vaitla, B. and Coates, J. (2014) 'How do indicators of household food insecurity measure up ? An empirical comparison from Ethiopia', Food Policy 47: 107-116. https://doi.org/10.1016/j.foodpol.2014.04.003. 
Mazvimavi, K. and Twomlow, S. (2009) 'Socioeconomic and institutional factors influencing adoption of conservation farming by vulnerable households in Zimbabwe', Agricultural Systems 101(1-2): 20-29. https://doi. org/10.1016/j.agsy.2009.02.002.

Mccarthy, N. and Brubaker, J. (2014) Climate-smart agriculture and resource tenure in sub-saharan africa: a conceptual framework. Rome: Food and Agriculture Organization of the United Nations.

McCord, P.F., Cox, M., Schmitt-harsh, M. and Evans, T. (2020) 'Crop diversification as a smallholder livelihood strategy within semi-arid agricultural systems near Mount Kenya', Land Use Policy 42(2015): 738-750. https://doi. org/10.1016/j.landusepol.2014.10.012.

Mmbando, F.E., Wale, E.Z. and Baiyegunhi, L.J.S. (2015) 'Determinants of smallholder farmers ' participation in maize and pigeonpea markets in Tanzania', Agricultural Economics Research, Policy and Practice in Southern Africa 54(1): 96-119. https://doi.org/10.1080/03031853.2014.974630.

Murendo, C., Kairezi, G. and Mazvimavi, K. (2020) 'Resilience capacities and household nutrition in the presence of shocks. Evidence from Malawi', World Development Perspectives 20(June 2019): 100241. https://doi. org/10.1016/j.wdp.2020.100241.

Musa, F.B., Kamoto, J.F.M., Jumbe, C.B.L. and Zulu, L.C. (2018) 'Adoption and the Role of Fertilizer Trees and Shrubs as a Climate Smart Agriculture Practice: The Case of Salima District in Malawi', Environments 5: 122. https://doi.org/10.3390/environments5110122.

NEPAD. (2013) Agriculture in Africa: Transformation and Outlook. Johannesburg: NEPAD (New Partnership for African Development).

Ng'ombe, J.N., Kalinda, T.H. and Tembo, G. (2017) 'Does adoption of conservation farming practices result in increased crop revenue? Evidence from Zambia', Agrekon (Agricultural Economics Research, Policy and Practice in Southern Africa) 56(2): 205-221. https://doi.org/10.1080/03031853.2017.1312467.

Ngwira, A., Johnsen, F.H., Aune, J.B., Mekuria, M. and Thierfelder, C. (2014) 'Adoption and extent of conservation agriculture practices among smallholder farmers in Malawi', Journal of soil and water conservation 69(2): 107-119. https://doi.org/10.2489/jswc.69.2.107.

Nhemachena, C., Hassan, R. and Chakwizira, J. (2014) 'Analysis of determinants of farm-level adaptation measures to climate change in Southern Africa', Journal of Development and Agricultural Economics 6(5): 232241. https://doi.org/10.5897/JDAE12.0441.

Nkhoma, P.R. (2018) 'The evolution of agricultural input subsidy programs : contextualizing policy debates in Malawi's FISP', World Development Perspectives 9:12-17. https://doi.org/10.1016/j.wdp.2017.12.002.

Ogutu, S.O. and Qaim, M. (2019) 'Commercialization of the small farm sector and multidimensional poverty', World Development 114: 281-293. https://doi.org/10.1016/j.worlddev.2018.10.012.

Pannell, D.J., Llewellyn, R.S. and Corbeels, M. (2014) 'Agriculture, Ecosystems and Environment: The farm-level economics of conservation agriculture for resource-poor farmers', Agriculture, Ecosystems and Environment 187: 52-64. https://doi.org/10.1016/j.agee.2013.10.014.

Pender, J. and Alemu, D. (2007) Determinants of Smallholder Commercialization of Food Crops IFPRI Discussion Paper No. 00745. Washington, DC: International Food Policy Research Institute.

Pingali, P., Khwaja, Y. and Meijer, M. (2005) Commercializing Small Farms: Reducing Transaction Costs. ESA Working Paper No. 05-08. Rome: Food and Agriculture Organization of the United Nations.

Pingali, P.L. and Rosegrant, M.W. (1995) 'Agricultural commercilisation and diversification: processes and policies', Food Policy 20(3): 171-185.

Radchenko, N. and Corral, P. (2018) 'Agricultural Commercialisation and Food Security in Rural Economies: Malawian Experience', Journal of Development Studies 54(2): 256-270. https://doi.org/10.1080/00220388.2017. 1283014. 
Ragasa, C. and Mazunda, J. (2018) 'The impact of agricultural extension services in the context of a heavily subsidized input system: The case of Malawi', World Development 105: 25-47. https://doi.org/10.1016/j. worlddev.2017.12.004.

Ragasa, C. and Niu, C. (2017) The State of Agricultural Extension and Advisory Services Provision in Malawi: Insights from household and community surveys (Technical Report). Lilongwe: International Food Policy Research Institute.

Richards, M., Arslan, A., Cavatassi, R. and Rosenstock, T. (2019) Climate change mitigation potential of agricultural practices supported by IFAD investments An ex ante analysis (IFAD Research Series No. 35). Washington DC: International Fund for Agricultural Development.

Rios, A.R., Masters, W.A. and Shively, G.E. (2009) 'Farm Productivity and Household Market Participation: evidence from LSMS Data', Contributed Paper prepared for presentation at the International Association of Agricultural Economists Conference, Beijing, China, August 16-22, 2009.

Rubhara, T. and Mudhara, M. (2019) 'Commercialization and its determinants among smallholder farmers in Zimbabwe. A case of Shamva District, Mashonaland Central Province', African Journal of Science, Technology, Innovation and Development 11(6): 711-718. https://doi.org/10.1080/20421338.2019.1571150.

SOAS (School of Oriental and African Studies), Wadonda Consult, Overseas Development Institute and Michigan State University. (2008) Evaluation of the 2006/7 Agricultural Input Supply Programme, Malawi: Final Report. London: SOAS.

Shiferaw, B., Kebede, T., Kassie, M. and Fisher, M. (2015) 'Market imperfections, access to information and technology adoption in Uganda: challenges of overcoming multiple constraints', Agricultural Economics 46: 475488. https://doi.org/10.1111/agec.12175.

Shiferaw, B., Tesfaye, K., Kassie, M., Abate, T., Prasanna, B.M. and Menkir, A. (2014) 'Managing vulnerability to drought and enhancing livelihood resilience in sub-Saharan Africa: Technological, institutional and policy options', Weather and Climate Extremes 3: 67-79. https://doi.org/10.1016/j.wace.2014.04.004.

Sibande, L., Bailey, A. and Davidova, S. (2017) 'The impact of farm input subsidies on maize marketing in Malawi', Food Policy 69: 190-206. https://doi.org/10.1016/j.foodpol.2017.04.001.

Simtowe, F., Asfaw, S. and Abate, T. (2016) 'Determinants of agricultural technology adoption under partial population awareness: the case of pigeonpea in Malawi', Agricultural and Food Economics 4(7): 1-21. https://doi. org/10.1186/s40100-016-0051-z.

Tambo, J.A. and Mockshell, J. (2018) 'Differential Impacts of Conservation Agriculture Technology Options on Household Income in Sub-Saharan Africa', Ecological Economics 151(April): 95-105. https://doi.org/10.1016/j. ecolecon.2018.05.005.

Teklewold, H., Kassie, M. and Shiferaw, B. (2013) 'Adoption of Multiple Sustainable Agricultural Practices in Rural Ethiopia', Agricultural Economcis 64(3): 597-623. https://doi.org/10.1111/1477-9552.12011.

Theriault, V., Smale, M. and Haider, H. (2017) 'How Does Gender Affect Sustainable Intensification of Cereal Production in the West African Sahel? Evidence from Burkina Faso', World Development 92: 177-191. https://doi. org/10.1016/j.worlddev.2016.12.003.

Thierfelder, C. and Wall, P.C. (2009) 'Effects of conservation agriculture techniques on infiltration and soil water content in Zambia and Zimbabwe', Soil and Tillage Research 105: 217-227. https://doi.org/10.1016/j. still.2009.07.007.

UNDP. (2020) Human Development Report 2020. The next frontier: Human development and the Anthropocene. New York: UNDP.

Wanyama, J.M., Nyambati, E.M., Mose, L.O., Mutoko, C.M., Wanyonyi, W.M., Wanjekeche, E. and Rono, S.C. (2010) 'Assessing impact of soil management technologies on smallholder farmers ' livelihoods in North Western Kenya', African Journal of Agricultural Research 5(21): 2899-2908. 
Woldeyohanes, T., Heckelei, T. and Surry, Y. (2017) 'Effect of off-farm income on smallholder commercialization : panel evidence from rural households in Ethiopia', Agricultural Economcis 48: 207-218. https://doi.org/10.1111/ agec.12327.

Wollni, M., Lee, D.R. and Thies, J.E. (2010) 'Conservation agriculture, organic marketing , and collective action in the Honduran hillsides', Agricultural Economcis 41: 373-384. https://doi.org/10.1111/j.1574-0862.2010.00445.x.

Woodridge, J.M. (2010) Econometric analysis of cross section and panel data. London: MIT Press.

Singh, I., Squire, L. and Strauss, J. (1986) Agricultural Housheold Models: Exptensions, Aplications and Policy. Baltimore and London: The Johns Hopkins University Press.

World Bank. (2009) World Development Report 2008: Agriculture for Development. Washington DC: World Bank.

Wossen, T., Abdoulaye, T., Alene, A., Haile, M.G., Feleke, S., Olanrewaju, A. and Manyong, V. (2017) 'Impacts of extension access and cooperative membership on technology adoption and household welfare', Journal of Rural Studies 54 223-233. https://doi.org/10.1016/j.jurstud.2017.06.022. 


\section{APPENDICES}

Table A1: Description of variables

\begin{tabular}{|c|c|c|c|}
\hline Variable & Description & $\begin{array}{l}\text { Expected } \\
\text { relationship } \\
\text { with CSA }\end{array}$ & $\begin{array}{l}\text { Expected } \\
\text { relationship } \\
\text { with } \mathrm{HCl}\end{array}$ \\
\hline Extent of CSA adoption & Number of CSA practices used & - & + \\
\hline Market participation & $\mathrm{HCl}=$ crop sales value/ harvest value & - & - \\
\hline $\mathrm{m}$ & $\begin{array}{l}\text { Age of household head (years), gender of household } \\
\text { head }\end{array}$ & $+/-$ & $+/-$ \\
\hline Household education level & Maximum years of schooling in a household & + & - \\
\hline Household size & Adult equivalents & + & $+/-$ \\
\hline Durable assets & Asset index & + & + \\
\hline Livestock assets & TLU & + & + \\
\hline Extension services access & $\begin{array}{l}\text { Received any agriculture extension }(0 / 1) \text {, Received } \\
\text { extension on farm business management (FBM) } \\
(0 / 1) \text {, Community has a lead farmer }(0 / 1) \text {, Household } \\
\text { has a member of farmer club }(0 / 1) \text {, Number of GAPs } \\
\text { with extension provided }\end{array}$ & + & + \\
\hline Land holding & Land holding size (ha) & + & + \\
\hline Crop diversification & Number of crops cultivated (\#) & + & + \\
\hline Gender of decision maker & $\begin{array}{l}\text { Male head is the plot manager }(0 / 1) \text {, Male head } \\
\text { controls crop income }(0 / 1)\end{array}$ & + & + \\
\hline Farming characteristics & $\begin{array}{l}\text { Household hired agricultural labour }(0 / 1) \text {, Household } \\
\text { obtained credit }(0 / 1) \text {, Household received subsidized } \\
\text { fertiliser }(0 / 1) \text {, Household purchased commercial } \\
\text { fertiliser }(0 / 1)\end{array}$ & + & + \\
\hline Food security situation & Coping strategy index & $+/-$ & - \\
\hline Agricultural shocks experience & Number of agricultural shocks experienced & + & - \\
\hline
\end{tabular}

Notes: the symbols + and - refers to a positive and negative relationship, respectively.

Source: Authors' own 
Table A2: Double-hurdle estimates of market participation

\begin{tabular}{|c|c|c|c|c|}
\hline & \multicolumn{2}{|c|}{ Market participation } & \multicolumn{2}{|c|}{ Extent of market participation } \\
\hline & Coeff & SE & Coeff & SE \\
\hline Number of CSA practices & $0.084^{\star \star}$ & $(0.036)$ & 0.007 & $(0.005)$ \\
\hline Age of household head & 0.007 & (0.009) & 0.001 & $(0.001)$ \\
\hline Male-headed household & 0.127 & $(0.236)$ & -0.010 & $(0.043)$ \\
\hline Maximum years schooling in household & $0.051^{*}$ & $(0.030)$ & 0.003 & $(0.005)$ \\
\hline Adult equivalent & $-0.103^{\star}$ & $(0.057)$ & -0.008 & $(0.008)$ \\
\hline Asset index & -0.052 & $(0.164)$ & 0.009 & $(0.028)$ \\
\hline TLU & 0.294 & $(0.190)$ & 0.003 & $(0.010)$ \\
\hline Received FBM extension & 0.243 & $(0.213)$ & 0.030 & $(0.029)$ \\
\hline Presence of lead farmer (0/1) & 0.256 & $(0.206)$ & 0.032 & $(0.029)$ \\
\hline Land (ha) & -0.032 & $(0.038)$ & 0.005 & $(0.005)$ \\
\hline Received off-farm income (0/1) & 0.196 & $(0.212)$ & 0.021 & $(0.031)$ \\
\hline Number of crops cultivated & $0.565^{\star \star \star}$ & $(0.098)$ & - & - \\
\hline Male head makes decisions on income $(0 / 1)$ & 0.203 & $(0.203)$ & 0.001 & $(0.032)$ \\
\hline Hired agricultural labour (0/1) & -0.128 & $(0.238)$ & 0.002 & $(0.033)$ \\
\hline Obtained credit (0/1) & -0.315 & $(0.348)$ & 0.047 & $(0.049)$ \\
\hline Farm input subsidy beneficiary (0/1) & 4.926 & $(222.340)$ & 0.059 & $(0.050)$ \\
\hline Bought commercial fertiliser (0/1) & -0.226 & (0.199) & 0.048 & $(0.030)$ \\
\hline Member of farmer club (0/1) & 0.333 & $(0.380)$ & 0.004 & $(0.043)$ \\
\hline Coping strategy index & -0.006 & $(0.010)$ & -0.002 & $(0.002)$ \\
\hline Mchinji District (0/1) & -0.178 & $(0.178)$ & $0.087^{\star \star \star}$ & $(0.027)$ \\
\hline Original household (0/1) & $-0.753^{\star \star}$ & $(0.302)$ & $-0.094^{*}$ & $(0.049)$ \\
\hline Inverse Mills Ratio & - & - & 0.049 & $(0.072)$ \\
\hline Constant & $-0.921^{*}$ & $(0.485)$ & $0.522^{\star \star \star}$ & $(0.094)$ \\
\hline Sigma constant & - & - & $0.253^{\star \star \star}$ & $(0.010)$ \\
\hline Chi-squared LR & & & 99.016355 & \\
\hline Log likelihood & & & $-159.18425^{\star \star \star}$ & \\
\hline Number of observations & & & 470 & \\
\hline
\end{tabular}

Standard errors in parentheses

${ }^{*} p<0.10,{ }^{* *} p<0.05,{ }^{* * *} p<0.01$

Source: Authors' own 
Matita, M., Chirwa, E.W., Zingwe, D. and Mazalale, J. (2022) Use of Climate-Smart Agriculture Practices and Smallholder Farmer Market Participation in Central Malawi. APRA Working Paper 81. Brighton: Future Agricultures Consortium

(c) APRA 2022

ISBN: 978-1-78118-910-8

DOI: 10.19088/APRA.2022.003

\section{(cC) BY-NC-ND}

This is an Open Access report distributed under the terms of the Attribution-Non Commercial-No Derivs 4.0 Unported (CC BY-NC-ND 4.0) Attribution - You must give appropriate credit, provide a link to the license, and indicate if changes were made. You may do so in any reasonable manner, but not in any way that suggests the licensor endorses you or your use. NonCommercial — You may not use the material for commercial purposes. NoDerivatives - If you remix, transform, or build upon the material, you may not distribute the modified material. You are free to: Share - copy and redistribute the material in any medium or format.

https://creativecommons.org/licenses/by-nc-nd/4.0/legalcode

If you use the work, we ask that you reference the APRA website (www.future-agricultures.org/apra/) and send a copy of the work or a link to its use online to the following address for our archive: APRA, Future Agricultures Consortium, University of Sussex, Brighton BN1 9RE, UK (apra@ids.ac.uk)

All APRA Working Papers go through a review process before publication.

\section{@creative}

\section{DO YOU HAVE COMMENTS ON THIS PAPER?}

We would welcome your feedback on this working paper!

To provide brief comments, please follow this link to our short APRA Working Paper Feedback form: https://goo.gl/forms/1iVnXhhrIGesfR9

Agricultural Policy Research in Africa (APRA) is a programme of the Future Agricultures Consortium (FAC) which is

generating new evidence and policy-relevant insights on more inclusive pathways to agricultural commercialisation in sub-Saharan Africa. APRA is funded with UK aid from the UK Foreign, Commonwealth \&

Development Office (FCDO) and will run from 2016-2022.

The APRA Directorate is based at the Institute of Development Studies (IDS), UK (www.ids.ac.uk), with regional hubs at the Centre for African Bio-Entrepreneurship (CABE), Kenya, the Institute for Poverty, Land and Agrarian Studies (PLAAS), South Africa, and the University of Ghana, Legon. It builds on more than a decade of research and policy engagement work by the Future Agricultures Consortium (www.future-agricultures.org) and involves more than 100 researchers and communications professionals in Africa, UK, Sweden and USA. 